\title{
CORRECTION \\ Correction: Clinical electrophysiology of the optic nerve and retinal ganglion cells
}

Oliver R. Marmoy (D) and Suresh Viswanathan

(C) The Author(s) 2021

Eye (2023) 37:1290; https://doi.org/10.1038/s41433-021-01798-2

Correction to: Eye https://doi.org/10.1038/s41433-021-01614-x, published online 11 June 2021

Figure 1 illustration had an error-in the second panel (the PhNR waveform), the ' $a$ ' and ' $b$ ' labels were the wrong way around.

The original article has been corrected (c) Open Access This article is licensed under a Creative Commons Attribution 4.0 International License, which permits use, sharing, adaptation, distribution and reproduction in any medium or format, as long as you give appropriate credit to the original author(s) and the source, provide a link to the Creative Commons license, and indicate if changes were made. The images or other third party material in this article are included in the article's Creative Commons license, unless indicated otherwise in a credit line to the material. If material is not included in the article's Creative Commons license and your intended use is not permitted by statutory regulation or exceeds the permitted use, you will need to obtain permission directly from the copyright holder. To view a copy of this license, visit http://creativecommons. org/licenses/by/4.0/.

(c) The Author(s) 2021 